\section{THE THEORY OF EVOLUTION IN GERMANY}

PROF. HAECKEL, of the University of Jena, may be regarded as the most eminent living representative of the doctrine of evolution in Germany. He has won a name for himself during the last ten years as the author of several remarkable works in various sections of Natural History; specially should be mentioned his monograph on the Radiolaria (Berlin, 1862), which is, according to Huxley, one of the most solid and importunt contributions to zoology that have appeared for a long time. We owe also to him a monograph on the Monads (Fournal de Fena pour la Médecine, \&c., 1868), the simplest of known organisms, and another on the Geryonida or Hydromeduse (Leipzig, 1865); a history of the development of the Siphono. phore, a work crowned by the Academy of Utrecht (1869); a paper on the Sarcode bodies of the Rhizopoda (in the fou nal de Zoologie Scientifique, Leipzig, 1865); "Considerations on the Division of Labour in Nature and among Men" (in the collection of scientific treatises of Virchow and Holzendorff, 1869 ); and an essay on the "Origin and the Genealogical Tree of the Human Race" (in the same collection, 1868 ; 2nd edition, I870). There has just appeared a monograph on the Calcareous Sponges (See NATURE, vol. vii. p. 279), on which the author has been engaged for five years. But his principal work is undoubtedly his "Morphology of Organisms," in which he has condensed the result of all his researches, and unfolded his views on Nature as a whole, its history, its constitution, and its development : it is a learned treatise on natural philosophy, in which the author has adopted out and out the system of Darwin. Indeed, on more than one point he goes much farther than his master, and does not shrink from any of the extreme consequences of principles which are simply stated by the English philosopher : it may with truth be said that he is more Darwinian than Darwin himself. He aims, in fact, at filling up the chasm which separates the organic and inorganic kingdoms, and is inclined to endow with life everything that has being, down to crystals and the smallest molecule of matter. Haeckel, with his comprehensive and philosophic mind, has more than once applied the theory of evolution to certain moral phenomena, and notably to politics, while Darwin has always shown considerable reserve in this direction. With respect, also, to the simian origin of man, he is much more explicit and precise than the English naturalist. In sbort, as he does not confine himself simply to the exposition of theories and principles, as he seeks to recover the marks of development in the particular genealogy of animal and vegetable organisms, he is compelled to commit himself to a great number of hypotheses, whose boldness it is impossible to deny. We do not speak thus in the way of reproach ; we are none of those who think that science can live on experiment alone; hypothesis has always preceded experiment, and has seemed to incite and throw light upon it; it is the torch of induction, and without it the human mind would be doomed to sterility. Goethe has truly said that bad hypotheses are better than none at all. All that we ought to insist on is, that a hypothesis be abandoned the moment it is found to contradict certain facts, or when the same facts are more satisfactorily explained by a new hypothesis. One hypothesis may be better than another in three points-(I) when it accounts for a greater number of facts ; (2) when it explains them by a smaller number of causes; and (3) when it makes use only of known causes, and involves a smaller number of accessory hypotheses. This is why Darwinism is preferable to supernatural hypotheses; it only applies to the whole round of natural phenomena causes which undoubtedly explain particular facts-natural selection, adaptation, and heredity.

Haeckel has with justice observed that if the doctrine of evolution has not yet been universally adopted, it ought to be attributed to the want of philosophic culture on the part of the great majority of contemporary naturalists; and this reproach is specially deserved by France, where Darwinism has hitherto been much less understood than in England and Germany. "The numerous errors of speculative philosophy during the first thirty years of our century have brought such discredit on philosophy as a whole among the advocates of the exact and empirical method, that the latter at present labour under the strange delusion that the edifice of the natural sciences can be built up by means of facts alone without philosophic connection,-with

* Translated from an article by M. Léon Dumont in La Révue Scicriti. fique for J anuary 25,1873 . simple notions unenlightened by any general conception. If a purely speculative work undistirbed by the indispensable conditions of empirical facts is a chimerical edifice whose inanity is exposed by the first experiment, on the other hand, a purely empirical doctrine, composed exclusively of facts, is only a formless heap, unworthy of the name of structure. Rough facts are not the only materials; philosophic thought alone can rear them into a science. From this absence of the power of philosophising among naturalists proceed those gross mistakes in the elements of logic, that incapacity to draw the simplest conclusions, which are too clearly seen at the present day in all branches of the natural sciences, but particularly in zoology and botany." *

Haeckel has given a résumé of his theories as a whole in a series of lectures delivered at Jena in the Winter of $1867-68$. These lectures have been re-published under the title of "Natural History of Creation" (Berlin, I868; 2nd ed. 1870), in a volume which has already gone through several editions. What follows is an analytical exposition of the most important parts of this work. The three sections which immediately follow contain the substance of the 12th, I 3 th, I4th, and I $5^{\text {th }}$ lectures, which form a division of Haeckel's work under the title of "Principal Characteristics and Fundamental Laws of the theory of Evolution." Haeckel discusses those facts of Embryology, Palieontology, and Chorology, or the geographical distribution of living beings, which are calculated to throw light upon the science of the development of species.

\section{Embryology}

It is astonishing how much ignorance even now prevails upon the embryonic development of man and animals generally. Just as the originator of the theory of evolution-Lamarck-had to wait half a century before Darwin came to rescue his doctrine from oblivion, and impart to it new life, so Wolff's theory of Epigenesis, published in 1759 , remained almust unknown till 1803, when there appeared Oken's " History of the develop" ment of the Intestinal Canal." It was only then that the study of Ontogenesis began to spread, and soon there appeared the classic researches of Pander (18r7), and Baer (I8r9). The latter especially, in a book which marks an epoch ("History of the Development of Animals"), has established the most important facts of the embryology of the vertebrates with so much intelligence and philosophic depth, that his doctrines have become the indispensable basis for the study of that group of animals to whicl men belong.

At the outset of his existence, man, like every other animal organism, is only an egg, a simple little cell, whose diameter is only one-fourth of a millimetre at the most. It differs from the primordial cellule of the other mammalia only in its chemical constitution and the molecular composition of the albuminous matter of which the egg essentially consists. And yet these differences cannot be directly perceived by any means at our disposal ; but we are compelled by indirect conclusions to suppose their existence as the prime cause of the differerce in individuals. The human egg encloses all the essential elements of a simple organic cellule: a protoplasm which bears the name of vitellus, and a nucleus or germinal vesicle. This nucleus is a small sphere itself enclosing another nucleus much smaller still, the nucleolus; exteriorly the protoplasm is enveloped by a mem. brane which is known by the name of zona pellucida. The eggs of many of the lower animals, as the greater part of the medusæ, are on the contrary naked cells, which do not posiess this envelope.

As soon as the egg of the mammal is completely developed, it leaves the ovary and descends, by the narrow canal of the oviduct, into the uterus, where, after fecundation, it becomes an embryo. This transformation is thus brought about:- the original cellule becomes aivided into two cellules; on the primitive nucleolus are formed two new specks, and the nucleus becomes separated into two vesicles, each of which takes with it half of the protoplasm. The result of this process is that in the heart of the vitelline membrane, which alone is not divided, two cellules.are found in juxtaposition, differing from the original only in being unenveloped. Each of these new cellules is in its turn divided into two others, so as to form four, which in the same way become eight, these eight, sixteen, and so on ; these successive segmentations producing an agglomeration of cellules, in outward appearance resembling a mulberry. . The further development consists in these cells assuming the shape of a sac (vesicula blastodermica), in the interior of which a liquid collects; shortly, on a point of the wall which is composed of these cells

* General Mcrphology, I. 63; I1. 447. 
is produced a disc-like coagulation; their number rapidly increases, and this particular condensation becomes the embryo strictly so called, while the remainder of the blastoderm serves only for its nourishment. The embryo soon begins to broaden into the form of a biscuit. Three leaves or layers of cellules can be distinguished, superposed like envelopes upon each other, and each having its particular place in the construction of the living being; from the exterior leaf is formed the epidermis and the central parts of the nervous system, the spinal marrow and the brain ; from the central layer is formed the interior membrane which lines the digestive canal from the mouth to the anus, with all the glands that are attached to it (the lungs, the liver, the salivary glands, \&c.) ; the intermediate layer is the source of all the other organs.

The processes by which the three layers of cellules give birth to the most complicated organs can all be reduced-(I) To new segmentations, and consequently to an increase in the number of the cells ; (2) To the division of labour or the differentiation of these cellules ; (3) To the combination of these cellules, differently developed. The cellules which comprise a living organism may thus be compared to the citizens of a state, some of whom have one set of functions to perform, others another ; the division of labour, and the organic perfection which results from it, enables the state to accomplish certain undertakings which would be impossible to isolated individuals. Every living organism composed of many cellules resembles a sort of republic capable of accomplishing certain organic functions, which could not be discharged by a single cell, an amaba, or a monocellular plant. No rational mind would seek to explain by superhuman intervention the public weal which accrues to political society, from the harmony of particular actions ; so also in the organism, all the adaptations to ends ought to be regarded as the natural and necessary consequence of co-operation, of the differentiation and the perfection of the cellules, and not as the intentional work of a supernatural will.

Until the brain begins to show itself distinctly, it is scarcely possible to recognise any difference between the embryos of the different vertebrata, or at least of the three superior classesreptiles, birds, and mammals. Why, then, should any one now refuse to admit the most important consequence of the theory of evolution, according to which men have descended from simious or even inferior mammals? Are the phenomena of the development of the individual man, the earliest characteristics of which are given above, less marvellous? Is it not in the highest degree astonishing that all the vertebrate animals, belonging to the most diverse classes-fishes, amphibia, reptiles, birds, and mammals -cannot, in the earliest stages of their embryonic development, be distinguished from each other, and that even at a much later stage, when reptiles and birds are distinctly separated from mammalia, man and the dog are still almost identical? The development of the individual (ontogenesis) is as difficult to explain as that of the species (Phylogenesis). It may be even said that it is still more so, seeing that it has an infinitely shorter time in which to be accomplished. The former is nothing more than a compact reproduction of the latter, and Haeckel rightly finds in this parallelism the most incontestible proof in favour of the theory of evolution. Man and the superior vertebrata reproduce in the earlier phases of their development conditions which last through the life of the lower orders of fishes; they then pass into forms which are characteristic of the amphibia; the marks of the mammalia appear only at a later stage, and even here are discovered a succession of degrees which correspond to the charac. ters of different species or families. It is the same order in which the palæontological history of the earth shows us the successive production of the different animal forms-first the fishes, then the amphibia, next the inferior mammals, and last the superior mammals.

Side by side with these two orders of evolution there is a third parallel with them : it is that which is found particularly expounded in the works of Cuvier, Goethe, Meckel Johannes Müller, Gegenbaur, Huxley, and forms the subject of comparative anatomy. This science seeks to determine what is common to the forms of different species, and studies living beings from the point of view of the scale of perfection. In this respect also we find that fishes, amphibia, and the inferio mammals stand in the same relation to man as from the stand. point of embryonic evolution and of palæontology. Now, this triple parallelism of individual development, of palæontological development, and of systematic development, is completely explained by the theory of transformation, by the laws of heredity and adaptation, while no opponent of the theory of evolution has ever been able to account for it in a natural and philosophic manner. Haeckel concludes from this that we shall be compelled to admit Lamarck's theory of evolution, if we are not led to accept Darwin's theory of selection.

\section{SOCIETIES AND ACADEMIES \\ LONDON}

Royal Society, Feb. 20.- "On the Anatomy of the Land Planarians of Ceylon." By H. N. Moseley, M.A., Exeter College, Oxford.

Two new species of Land Planarians from Ceylon are a escribed as belonging to the genus Bipalium (Stimpson), B. Ceres, the other to that of Rynchodemus, $R$. Thwaitesii.

With regard to the habits of Bipalium, the most interesting facts noted are that these animals use a thread of their bodyslime for suspension in air, as aquatic Planarians. were observed to do for their suspension in water by $\mathrm{Sir} J$. Dalyell, and the cellar-slug does for its suspension in air. The anatomy of the Planarians was studied by means of vertical and longitudinal sections from hardened specimens. The skin in Bipalium and Rynchodemus closely conforms to the Planarian type, but is more perfectly differentiated histologically than in aquatic species, and approaches that of the leech in the distribution, colour, and structure of its pigment, and especially in the arrangement of the glandular system. The superficial and deep glandular systems of the leech are both here represented. In $B$. Ceres peculiar glandular structures exist, which may foreshadow the segmental organs of Annelids, it being remembered that these segmental organs are solid in an early stage of development. Rod-like bodies are present in abundance, though, singularly enough, Max Schultze failed to find any in Geoplana. These rod-like bodies are probably homologous with the nail-like bodies of Nemertines; and it is possible that the setæ of Annelids are modifica. tions of them.

The muscular arrangement in Bipalium, which is very complex, throws great light on the homologies between the muscular layers of Turbellaria and those of other Vermes. In Bipalium there is an external circular muscular coat, which even presents the same imbricated structure which is found in it in leeches and other worms. In Dendrocalum lacteum there is also an external circular coat. In cases where a distinct external circular muscular coat is absent, it is represented by a thick membrane, which is very probably contractile. All Turbellarians are built on the same essential type, as regards muscular arrangement, as are other worms. The general muscular arrangements in the bodies of the Bipalium and Rynchodemus have become much modified from those of flat Planarians by the pinching together and condensation of the body, but they are nevertheless referable to the same type.

The digestive tract consists of three tubes, one anterior, two posterior, as in other Planarians, and as in the embryo leech before the formation of the anus. Characteristic of land Plana. rians, and consequent on the condensation of the body, is the absence of all diverticulæ from the inner aspects of the two posterior digestive tubes. The close approximation of the intestinal diverticula in Bipalium and Rhynchodemus, and the reduction of the intervening tissue to a mere membranous septum, is very striking, and seems to foreshadow the condition of things in Annelids. The great difference in the form of the mouth in Rhynchodemus and Bipalium is also remarkable, considering the many points in which these forms are closely allied.

A pair of large water-vascular trunks, or, as they are here termed, primitive vascular trunks, are conspicuous objects in transverse sections of the bodies of Bipalium and Rhynchodemus. A peculiar network of connective tissue is characteristic of these vascular canals on section, and is shown to present exactly similar features in Leptoplana tremellaris, Dendrocalum lacteum, and Bothriocephalus latus. The close agreement in the relative position of the oviducts to the vascular canals in Dendrocolum and our land Planarians is very remarkable. The nerves ant ganglia of Planarians lie within the primitive vascular system, as do the corresponding structures within the primitive body-cavity of the leech.

A small marine Planarian was found to contain hæmoglobin. In Bipalium there are a series of separate testes disposed in pairs; as in the leech. In Rhynchodemus. the testicular cavities 